\title{
Socioeconomic and Lifestyle Assessment of Selected Forest Based Communities in Omo Biosphere Reserve, Ogun State, Nigeria
}

\author{
${ }^{* 1}$ OLADELE, TA; ${ }^{2}$ SRIDHAR, MKC; ${ }^{3}$ RAJI, AO \\ ${ }^{*}$ Department of Environmental Management, PAU Institute of Life and Earth Sciences(Including Health and Agriculture), PAULESI, \\ ${ }^{2}$ Department of Environmental Health Sciences, Faculty of Public Health, College of Medicine, ${ }^{3}$ Department of Agricultural and \\ Environmental Engineering, University of Ibadan, Ibadan, Nigeria. \\ *Corresponding Author Email: toyaderon.2013@gmail.com
}

\begin{abstract}
This study assessed socio-economic characteristics and lifestyle of selected forest based communities in Omo Biosphere Reserve, Ogun state in southwest Nigeria. The study aim was to explore the influence of socioeconomic factors on their lifestyle, quality of life and implications for forest environment. A sample of 180 respondents from three enclaves was selected using simple random sampling. Data collected was analyzed using SPSS version 20 and presented as Tables and charts. The results showed that 86.11 per cent of them were adults between ages 31 years and 70years who have families, responsibilities to cater for and have capacity to further expand their land into the forest. Only 2.2 per cent of the respondents have no formal education indicating a great decline in illiteracy. About 75.56 per cent have incomes ranging between 500,000 to 1,000,000 yearly. 58 per cent respondents have a household size ranging between 6-10 persons. 7.22 per cent have farm size less than $3 \mathrm{Ha}$ while the rest have more up to $10 \mathrm{Ha} .83$ per cent of the respondents were involved in cocoa farming while the remaining 17 per cent shared kola, palm and plantain crops farming. The type of constraints affecting the livelihood strategy often influences the mitigation measures undertaken by farmers in the study area. On health, malaria is the most prevalent disease experienced by 73.3 per cent respondents. However, the health care facilities are far from residents and also inadequate. As a result, about 95.6 per cent resorted to self-medication using herbs in case of illness. Younger and active age groups have their resultant socio-economic implications for forest environment but the obvious is its negativities in respect of exploiting more lands for farming hence, government should ensure increase awareness aimed at protecting the forest in order to prevent further forest encroachers.
\end{abstract}

DOI:https://dx.doi.org/10.4314/jasem.v24i3.1

Copyright: Copyright $(\subseteq 2020$ Oladele et al. This is an open access article distributed under the Creative Commons Attribution License (CCL), which permits unrestricted use, distribution, and reproduction in any medium, provided the original work is properly cited.

Dates: 25 January 2020; Revised: 11 February 2020; Accepted: 22 February 2020

Keywords: Socioeconomic, Lifestyle, Communities, Forest

The socio-economic conditions play an important role in characterizing the social life and behavior of an individual. The socio-economic status of an individual affects the patterns of interaction in the society. It is therefore, essential to analyze the socio-economic background of the respondents to understand the lifestyle of the respondents. Knowledge of socioeconomic background of a community is an indispensable prerequisite, for the understanding of the thought or behavior of its members. This holds good for all human communities, and more so in the case of rural communities, which are intrinsically more traditional in their structure (Desai, 1995).Socioeconomic status (SES) is a concept that summarizes an individual's social class position in society. Several conceptualizations of SES have been used, including material measures of income, occupation, and education as well as gradient- focused measures of relative status, relative deprivation, or class differences (American Psychological Association, 2007). In plain terms, it looks at the life around individuals and characteristics such as age, gender, race, religion, health, income, marital status, birth rate, death rate, average size of family, heritage, education, etc. It is basically a grouping of people by those characteristics. Although absolute levels of affluence (e.g., household income) are among the most commonly used measures of Socioeconomic status (SES) in research, over the past decade there has been increasing emphasis on the ability of social class gradients and perceived SES to better predict various social, behavioral and health outcomes (Adler and Snibbe, 2003).The influence of forest on the immediate environment forms part of a vast and complex relationship between environment and forest vegetation. Environment generally refers to the sum total of various components of universe that affect life on this planet such as soil, water, and climate etc. Man in generally interferes the environment by destroying vegetation through over-exploitation and mismanagement. In the past, consideration of forests, and influence on climate was focused at the 
microclimate or local level. More recently, increasing attention has been directed at the potential, impact of forests on global conditions. The forest environment or site consists of the physical environment surrounding the aerial portions of the tree (climatic factors) and that surrounding the subterranean portion (edaphic factor) and the third one is biotic factor. External influences, particularly fire, grazing animals and humans, affect markedly the nature of sites and their capacity to support tree growth. There is a general consensus that economic growth as measured by per capita income affects environmental quality (Constatini and Martini, 2010). Hence, there is need to assess the socioeconomic characteristics of the people living within the forest environment. Therefore, the study aim was to explore the influence of socioeconomic factors on their lifestyle, quality of life and implications for forest environment in order to identify opportunities for policy makers to prevent abuse of forest land.

\section{MATERIALS AND METHODS}

Study area: The study was carried out in three enclaves of Omo Biosphere Reserve (Osoko, Basiru and Oloji) of Ogun state. Omo Biosphere Reserve, which derives its name from River Omo that traverses it, is located between latitudes 6" $35^{\prime}$ to 7' $05^{\prime} \mathrm{N}$ and 4' 19' to 4' 40' $\mathrm{E}$ in the Ijebu area of Ogun State in southwestern Nigeria. The Reserve was constituted in 1925 and covers about 130500 hectares, about $20 \mathrm{~km}$ from the Atlantic coast in its southernmost parts. Geologically the Reserve lies on crystalline rocks of the undifferentiated basement complex which in the southern parts is overlain by Eocene deposits of sand, clay and gravel. The terrain is undulating and the maximum elevation of $150 \mathrm{~m}$ above sea level is towards the west while the lowest parts of the Reserve are in the south where the River Omo joins River Oni, the Reserve's eastern boundary, before flowing into the Lekki Peninsular on the Atlantic coast. There are swamps in the south especially near the junction of the two rivers. The soil is tropical ferruginous (OlaAdams, 2014).

Data collection: Data collection was based on exploratory and participatory social survey research method. In total, 180 households were randomly selected from three villages from the communities in the forest. A questionnaire survey was administered to the 180 households during fieldwork. These semistructured interviews were used to solicit local knowledge, opinions, and views of local livelihoods.

Sampling methods: A Geographical Information System (GIS) spatial coverage of the district and the location of the communities was mapped. In order to minimize selection biases, homogenous sampling was used. This is to purposively observe closest communities or enclaves to the forest, and random samples were drawn from each of the community for the sample on a proportional basis. A 5\% sampling target was set for each community within the survey. In survey research, a 5\% sample size is considered sufficient (Bartlett et al., 2001).

Table 1: Sample households of the three Enclaves

\begin{tabular}{|c|c|c|c|}
\hline No & Enclaves & $\begin{array}{l}\text { Population } \\
\text { Estimates }\end{array}$ & $5 \%$ Sampled $( \pm)$ \\
\hline 1 & Basiru & 300 & 15 \\
\hline 2 & Ohoko & 800 & 40 \\
\hline 3 & Oloji & 2000 & 125 \\
\hline \multicolumn{3}{|c|}{ Total sampled households } & 180 \\
\hline
\end{tabular}

Data Analysis: Data collected was analyzed using SPSS version 20 and presented as Tables and charts. Frequencies, percentages and chart were used to present the characteristics of households using Descriptive statistics to analyze the quantitative data.

\section{RESULTS AND DISCUSSION}

Gender: The study revealed that out of the total of 180 respondents, $95 \%(\mathrm{n}=171 / 180)$ were males while $5 \%$ $(n=9 / 180)$ were females. This gender distribution indicates that there were more than twice as many males as females in the sample.

Table 2: Socio-economic characteristics of respondents in the study area

\begin{tabular}{|c|c|c|c|}
\hline Variable & Items & Frequency & Percentage \\
\hline \multirow[t]{2}{*}{ Gender } & Male & $9(180)$ & $5(100)$ \\
\hline & Female & $171(180)$ & $95(100)$ \\
\hline \multirow[t]{7}{*}{ Age Grp. } & $30 \&$ Below & 8 & 4.44 \\
\hline & $31-40$ & 41 & 22.78 \\
\hline & $41-50$ & 45 & 25 \\
\hline & $51-60$ & 35 & 19.44 \\
\hline & $61-70$ & 34 & 18.89 \\
\hline & $71-80$ & 14 & 7.78 \\
\hline & $81-90$ & 3 & 1.67 \\
\hline \multirow[t]{4}{*}{ Education } & Illiterate & 4 & 2.22 \\
\hline & Primary & 64 & 35.56 \\
\hline & Secondary & 91 & 50.56 \\
\hline & Tertiary & 21 & 11.66 \\
\hline \multirow[t]{4}{*}{ Income } & $\begin{array}{l}\text { Low } \\
<500000\end{array}$ & 29 & 16.11 \\
\hline & Medium & 136 & 75.56 \\
\hline & $500000-10$ & & \\
\hline & $\begin{array}{l}\text { High } \\
>1000000\end{array}$ & 15 & 8.33 \\
\hline \multicolumn{4}{|l|}{ Household } \\
\hline \multirow[t]{3}{*}{ Size } & $5 \&$ Below & 70 & 38.89 \\
\hline & 6 to 10 & 105 & 58.33 \\
\hline & $>10$ & 5 & 2.78 \\
\hline \multirow[t]{3}{*}{ Religion } & Christian & 101 & 56.11 \\
\hline & Muslim & 74 & 41.11 \\
\hline & Traditional & 5 & 2.78 \\
\hline \multicolumn{4}{|l|}{ Home } \\
\hline \multirow[t]{3}{*}{ Structure } & Brick & & \\
\hline & Mud & 180 & 100 \\
\hline & Wood & & \\
\hline
\end{tabular}


Age Group: In the group-wise percentage distribution of age of respondents presented, It is observed that 4.44 per cent respondents are 30 years and below. This shows younger people are out of farming to acquire at least a form of basic education or skills. Age is a demographic factor. But it has deep sociological implications for social behavior. An overwhelming majority of 86.11 per cent were adults who are between 31 years and 70years of age. It means the respondents presumably are grown-ups, have children and family responsibilities. This also indicates that most of this larger percentage of the respondents is migrants from the urban areas who came to make use of the forest soil for farming purposes. A reasonable percentage of 7.78 respondents are adults above 70 years of age, which means age is telling but the environment is conducive for farming and the vast percentage of the previous age groups serves as laborers for this set of age group and the declining 1.67 per cent age group (81-90 years).

Education: The education level of respondent according to types of education reveals that 2.22 per cent of respondents have no basic form of education hence termed as illiterate. This shows illiteracy is fast declining even in remote areas. 35.56 per cent of the respondents have primary level of education. 50.56 per cent respondents have completed higher secondary level. The per cent of respondents who have tertiary education is 11.66 per cent of the total respondents. The data reveals that respondents who have basic education are interestingly above average per cent. Although, quality education can enhance their empowerment process, qualifying in that may enable them to gain socio-economically good positions. During the field work it was observed that a sizeable number of those respondents who have secondary education especially tertiary education are migrants to the enclaves mainly for the purpose of farming. Some are even teachers in urban areas. One can notice from the above analysis that majority of people now crave to be at least literate because literacy is important, as it is necessary for the development of personality.

Income: Background information collected about annual income of the respondents' shows in Table 2 that 75.56 per cent of them have a relatively medium income, while only 8.33 per cent have high income. However, 16.11per cent of the respondents have low income. It is clear that there is a clear income group differential among the respondents. Income is generally taken as an index of social status and influence of a person. Though, income is not an exclusive basis of influence but certainly an important basis. Although, it is noticed that most of them tend to hide information regarding their actual income, their continued migration is an indication that their farming business is profitable and rewarding.

Household size: The household is an important economic unit useful for planning purpose. The analyses carried out in table 2 shows that a chunk above average of the respondents ( 58 per cent) has a household size between six to ten (6-10) while the household size of 5 and below have a percentage of 39percent. The remaining 3 percent were household size above ten $(>10)$. It is observed that urbanization and modernization is gradually depleting large family size in Africa. However, people have different reasons for keeping various family sizes. To get a clear picture of this, Ominde and Ejiogu (1972) also indicated reasons for choice of family size in their writing, Population growth and economic development in Africa. Reasons indicated for family size are differences in age at marriage and in numbers marrying, prevalence of polygamy in African marriages with the possibility of favoring some wives in the making of love. High divorce and widowhood rates also have been espoused as a factor for the relative family size. As a result of prolonged lactation, ill health, malnutrition and life of hard labour were also some of the factors attributed to the various family sizes identified within the African societies.

Religion: In the Nigerian Society, religion has an important place. The religion plays an important role in shaping the norms and values of members of the society. 56.11per cent respondents are Christians while 41.11 per cent of respondents are Muslims, these number are fast catching up with the population of Christians. Hence there is no high differential between the two religions. The traditional religion has 2.78 per cent of the total respondents. However, during the survey, it was observed that a few of them have dual religion, but they were asked to state the major religion as the first.

Housing: The housing structure in the three enclaves assessed shows that 100 per cent of the respondents have mud houses with zinc roof and wooden windows. The structure of the houses is all the same, although, it varies in sizes. This observation shows that in spite of high income on the part of some, the home structure do not change, this further indicates that most of the residents are not permanent residents. Although, while some are from these enclaves, most of them are shuttling between the enclaves and urban areas as migrants while the forest reserve just serve as farm for them.

Cultivated Crops: Results in the Fig. 1 shows that 83 per cent of the respondents were involved in cocoa 
farming, implying that the farmers were relatively large scale cocoa producers, 7 per cent followed plantain farming, 6 per cent were into palm kernel farming and 4 per cent followed Kola farming. Cocoa has contributed to the economy of the country over the years and gained popularity because of the benefits from its earnings and its contribution to Gross Domestic Product (GDP) as the highest foreign exchange earner among all agricultural commodities (Oyekale et al., 2009).

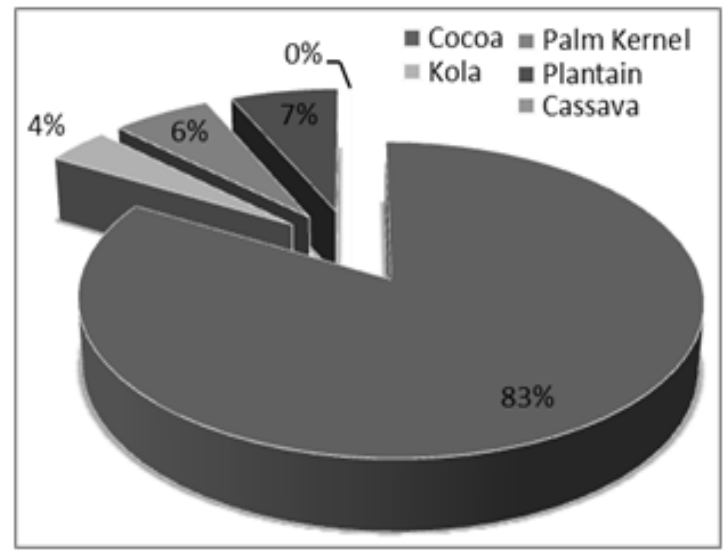

Fig 2: Crops Grown by Respondents

Most farmers had other sources of income generation apart from cocoa farming. That is, some had in addition, cassava, maize and plantain plantations. While, some of the farmers still engaged largely in production of crops such as palm kernel, Kola and plantain. The vast land in the forest gives room for the people to expand their farm for plantation farming.

Farm Size: The most critical issue confronting farming households is maintaining a sufficient level of income on their farm. Other concerns include the negative effect of a growing inequality in land ownership on broad-based rural development and growth, the detrimental environmental impacts (especially where land expansion occurs at the expense of forests), and the harmful effects of land speculation and inadequate technology on potential financial and economic benefits.

Table 3: Household farm size

\begin{tabular}{lll}
\hline Farm size( Ha) & Frequency(180) & Percentage(100) \\
\hline 1 to 2 & 13 & 7.22 \\
3 to 4 & 42 & 23.33 \\
5 to 6 & 90 & 50 \\
7 to 8 & 32 & 17.78 \\
9 to 10 & 3 & 1.67 \\
\hline
\end{tabular}

As shown in Table 3, it was observed that farm size between 5 to $6 \mathrm{Ha}$ recorded the highest frequency which is 50 percent, an average of the total population.
This is followed by 23.33 percent for farm sizes between 3 to $4 \mathrm{Ha}, 17.78$ per cent of the respondents have their farm sizes ranging between 7 to $8 \mathrm{Ha}$, we have only a few respondents about 1.67 per cent that has a farm size ranging between 9 to $10 \mathrm{Ha}$. Invariably, observing this trend, there is no large corporate farms in existence rather; they have small farms in various sizes benefitting from the commitment of family members, flexible labour supply and an intimate knowledge about local soil and climate. This in turn has helped them achieved a considerable degree of efficiency. Moreover, a study of U.S. farms found that an increase of farm size reduces, rather than increases, agricultural productivity (Ahearn et al., 2002). However, continuous migrants' encroachment into the forest lands has great implication for forest protection and conservation as the importance of the environment and forest ecosystem to human survival can never be underestimated.

Increase migration: The oldest enclave is Oloji, which have the largest estimated population from Table1. This is followed by Ohoko with a population estimate of 800 and finally Basiru with 300 estimated population. This suggests in this case that the longer the existence of the enclaves, the more they are being filled up with people. Although this does not hold true for all situation in the forest, some enclaves increase rapidly due to easy access into them while some that long exist do not increase at such pace. Currently, the influxes of people migrating to the forest continue to increase for different purposes. While the movement for some is to take advantage of free fertile land for farming activities due to increase in the rate of unemployment and ailing economy in the urban area. Some other are hoodlums invading and using the forested landscape for criminal activities e.g. kidnappers, robbers and cannabis cultivators. This is because the forest offer shelter and have resources that can support wanderers - like food or illegal logging to finance their activities. Others were reported to come for the collection of non-timber forest product for the purpose of trading.

Constraint to Livelihood and Coping Strategy: The type of constraints affecting the livelihood strategy often influences the mitigation measures undertaken by farmers in the study area. The study established that factors beyond farmers control like climate change affect individual farmer livelihood strategies, with varied consequences to their livelihood outcomes and the physical environment on which they depend for their wellbeing 
Table 4: Constraint to Livelihood and Coping Strategy

\begin{tabular}{llll}
\hline & $\begin{array}{l}\text { \% of Farmers } \\
\text { Indicating } \\
\text { Constraints }\end{array}$ & $\begin{array}{l}\text { Mitigation } \\
\text { Measures }\end{array}$ & $\begin{array}{l}\text { \% of Farmers } \\
\text { Identifying } \\
\text { Indicator as } \\
\text { Coping Strategy }\end{array}$ \\
\hline Constraints & 60.56 & Buying Foods & 81.1 \\
Crop loss & 56.67 & Use of Medicinal & \\
& 63.33 & Trees/Hospital & $95.6 / 13.9$ \\
$\begin{array}{l}\text { Illness } \\
\text { Death } \\
\text { Shortage of Labor/Income }\end{array}$ & 2.22 & Use of Laborers & 69.4 \\
Theft & 51.11 & Use of traditional & \\
$\begin{array}{l}\text { Damage to or Loss of } \\
\text { Dwelling or other structures }\end{array}$ & 36.11 & means & 24.4 \\
$\begin{array}{l}\text { Bush Fires } \\
\text { Pest }\end{array}$ & 15.56 & & \\
\hline
\end{tabular}

The respondents indicated that high invasion of pest, period of hunger, crop loss, illness and labour formed the bulky of farmer's constraints to adequate crop production. 77.8 per cent indicated the use of pesticides to combat pest invasion on about 93.9 per cent of the farmers who identified pest as a major constraint while the differential resort to other indigenous method. 63.3 per cent indicated illness as constraints to their livelihood strategy, this is remedied by the use of medicinal trees by 95.6 per cent and 13.9 per cent who visit hospital respectively. The use of natural cure has impacted them positively because in Table 5 below, 70 per cent of the respondent indicated that the hospital facility is too far which has the highest percentage of the reason why they are not consulting the hospital in case of illness. To the majority of the households, family labour was the main mode in crop production. In the past, farmers reported that they relied on their children for their farm labour requirements.

But today, most of their children are in schools. Majority of those who complete their education ignore farming and immigrate to the urban centers and cities in search of jobs. To mitigate these problems, some farmers 69.4 per cent resorted to use of hired labour. 60.56 per cent indicated they do experience some period of hunger which usually ranges between Januarys to march, this is otherwise known as the period of food insecurity. About 81 per cent resorted to buying foods during this period of food insecurity. Respondents had their hunger period any time their grown arable crops have been exhausted indicating that this proportion did not have surplus to keep and sell. The ability to accumulate assets under normal conditions enables households to draw on them during times of stress. Assets may be personal, sociopolitical, infrastructural, economic or ecological (Drimie and Casale, 2009). Household food security is highly dependent on the strength and ability of livelihood strategies to ensure that assets are available. The focus on livelihoods resulted in an awareness of the different abilities of households to cope with stressors, which undermine their ability to access food. While some households were observed to be severely affected during short-term setbacks and fluctuating levels of food security, others seemed to cope and recover (Chambers and Conway, 1992). Others constraints were theft 36.1 percent, but interestingly about 24.4 per cent indicated the use of traditional method of wading thieves off their farm. These include tying red cloth, using snail shells, clothes with old cowries, etc. while some of this items are harmless but just a way to scare hoodlums. Some can be really fetish and possess spiritual powers to harm victims. Death constraints have 2.2 per cent of the respondents either due to sickness, accident or old age.

\begin{tabular}{|c|c|c|}
\hline $\begin{array}{l}\text { Sickness/ } \\
\text { Disease }\end{array}$ & $\begin{array}{l}\text { Frequency } \\
\text { (180) }\end{array}$ & $\begin{array}{l}\text { Percentage } \\
(100)\end{array}$ \\
\hline Malaria & 132 & 73.33 \\
\hline Measles & 116 & 64.44 \\
\hline Ulcers & 98 & 54.44 \\
\hline Skin Infections & 56 & 31.11 \\
\hline Diarrhea & 38 & 21.11 \\
\hline Accident & 26 & 14.44 \\
\hline Hypertensions & 16 & 8.88 \\
\hline Others & 8 & 4.44 \\
\hline Other Fever & 7 & 3.89 \\
\hline
\end{tabular}

Prevalent Health challenges: Health is not a monopoly of the health sector; interlinkage is very important. Health contributes to socioeconomic goals and vice versa. Diseases can be seen as both an indicator and product of the structure of a community. Among the respondents, malaria is the most prevalent disease experienced to the tune of 73.3 per cent; it is followed by measles which has 64.4 per cent of the total respondents. The illness is perceived to usually occur in the dry season. 
Malaria is one of the most formidable and serious public health problems and Environmental changes have a great bearing on breeding habitats of different mosquito species that control adult population density. The relationship between climate variables and mosquito abundance can provide important information to determine parasite activity levels and, therefore, disease risk (Wegbreit and Reisen, 2000). Ulcer has about an average of 54.4 per cent of the respondents, about 21.1 per cent complained of diarrhea, 31.1 per cent for skin infections, 8.9 per cent for hypertensions, 14.4 per cent experienced motorbike accident as this is the means of transportation within the community. Other fever carries 7 per cent while some other complained of unexplainable illness totaling 8 percent of the respondents. The environment and lifestyle may be taken to encompass most factors and conditions that affect people's health e.g. a farmer who regularly leaves for the farm without breakfast or water may develop ulcer etc.

Reasons for not attending hospital: According to the study carried out, (Table 4), about 95.6 per cent of the respondents regularly take herbal medicine while 13.9 per cent visit hospital in cases of serious health conditions. The reasons for not consulting hospital is explained in Table 5, exactly 70 per cent responded that the facilities are too far hence they resorted to selfmedication by taking herbal medicine; 21. 67per cent claimed that the illness is too mild to be taken to the hospital; therefore, they diagnose the illness by themselves and treat with herbs also. The remaining 8.3 per cent added that the reason why some of them treat themselves is because the available medicine store they can find around can be very expensive compared with just walking to the nearby bush to find the supposed right combination of leaves or roots for their perceived ailments.

\begin{tabular}{lll}
\multicolumn{3}{c}{ Table 6: Reasons for not attending hospital } \\
\hline Reasons & Frequency & Percentage \\
\hline Facilities too far & 126 & 70 \\
Illness is Mild & 39 & 21.67 \\
Available Facilities too Costly & 15 & 8.33 \\
Total & 180 & 100 \\
\hline
\end{tabular}

Despite, increase awareness in the dangers of selfmedication, several benefits have been linked to appropriate self-medication, among them: increased access to medication and relief for the patient, the active role of the patient in his or her own health care, and reduced (or at least optimized) burden of governments due to health expenditure linked to the treatment of minor health conditions. However, selfmedication is far from being a completely safe practice, in particular in the case of non-responsible self-medication. Potential risks of self-medication practices include: incorrect self-diagnosis, delays in seeking medical advice when needed, infrequent but severe adverse reactions, dangerous drug interactions, incorrect manner of administration, incorrect dosage, incorrect choice of therapy, masking of a severe disease and risk of dependence and abuse (Esperanza, 2012).

Conclusion: Younger and active age groups have their resultant socio-economic implications for forest environment but the obvious is its negativities in respect of exploiting more lands for farming. This results in deforestation, depletion of forest cover for protection of water bodies etc. However, Agricultural livelihood alone is not sufficient to improve the communities' welfare. Rather, strengthening research and education in forest and environmental protection to equip the public and diversifying livelihood activities should be seen as a panacea to divert people encroaching into forest environment for alternatives. The government should thus be active in increasing awareness aimed at protecting and sustaining the forest in order to prevent further forest encroachers.

\section{REFERENCES}

Adler, NE; Snibbe, AC (2003). The role of psychosocial processes in explaining the gradient between socioeconomic status and health. Current Directions in Psychological Sci. 12: 119-123.

Ahearn, M; Yee, J; Huffman, W (2002). The Effect of Contracting and Consolidation on Farm Productivity.Paper presented at the Economics of Contracting in Agriculture Workshop, Annapolis, MD.

American Psychological Association (2007). Task Force on Socioeconomic Status. Report of the APA Task Force on Socioeconomic Status, Washington.

Bartlett, JE; Kotrlik, JW; Higgins, CC (2001). Organizational research: Determining appropriate sample size in survey research. Information Tech. Learning, and Performance J. 19(1): 43-50. 
Chambers, R; Conway, G (1992). Sustainable rural livelihoods: practical concepts for the $21 \mathrm{st}$ century. IDS discussion paper no. 296. Brighton: Institute of Development Studies, Sussex University.

Constatini, V; Martini, C (2010). A modified environmental Kuznets Curve for sustainable development assessment using panel data. Int. J. of Global Environ. 10 (2): 84 - 122.

Desai, IP (1995). Joint Family - An Analysis. Sociological Bulletin, Sept'95.

Drimie, S; Casale, M (2009). Multiple stressors in Southern Africa: the link between HIV/AIDS, food insecurity, poverty and children's vulnerability now and in the future. Aids Care. 21(1): 28-33.

Esperanza, M (2012). Ruiz Risks of self-medication practices: Quality Control of Medications. Department of Biological Sciences, Faculty of Exact Sciences, National University of La Plata (UNLP), 47 \& 115 (B1900AJI).
FAO (1981). Tropical Forest Resources Assessment Project: Forest Resources of Tropical Africa. Country Briefs.2: 359-379.

Ola-Adams, BA (2014). Biodiversity Inventory of Omo Biosphere Reserve. GEBR Project Report, Nigeria National MAB Committee.

Ominde, SH; Ejiogu, CN (1972). Population Growth and Economic Development in Africa. Population Council, New York, USA.

Oyekale, AS; olaji, MB; Olowa, OW (2009). The effects of climte change on cocoa production and vulnerability assessment in Nigeria. Agricultural J.4(2): 77-85.

Wegbreit, J; eisen, W K (2000). Relationships among weather, mosquito abundance, and encephalitis virus activity in California: Kern County 199098. J. Am MosqContr. Assoc. 16: 22-27. 